\title{
Clay's Variation characteristics in the Compound Soil of Arsenic Sandstone and Sand under Corn Conditions
}

\author{
Zhang Ruiqing ${ }^{1,2,3,4}$ \\ 1. Shaanxi Provincial Land Engineering Construction Group Co., Ltd., Xi'an 710075, China; \\ 2. Key Laboratory of Degraded and Unused Land Consolidation Engineering, the Ministry of Land \\ and Resources, Xi'an 710075, China; \\ 3. Shaanxi Provincial Land Consolidation Engineering Technology Research Center, Xi'an 710075, \\ China; \\ 4. Institute of Land Engineering and Technology, Shaanxi Provincial Land Engineering \\ Construction Group Co., Ltd., Xi'an 710075, China
}

Keywords: Pisha sandstone; Sand; Particle

Abstract: By studying the variation features of $0-70 \mathrm{~cm}$ soil layer clay particles composited by mixture of Pisha sandstone and sand in different proportions, theory basis is provided in order to promote the sustainable utilization of $\mathrm{Mu}$ Us Sandy Land. Three types of composite soil patterns that the mixing ratios were 1:1, 1:2 and 1:5 respectively between Pisha sandstone and sand were set in Fuping, Shannxi from 2010 to 2012; soil clay content was measured after crop harvesting, to analyze the change features of clay particles in composite soil of different mixing ratio. In three types of composite soil, clay particles are mainly concentrated at $0-30 \mathrm{~cm}$ on the soil surface, clay content is low subsoil. In terms of the mixing ratio of different Pisha sandstone and sand, on account of the higher proportion of Pisha sandstone in 1:1 composite soil, the clay content is the highest in topsoil, the size relationship of which is 1:1>1:2>1:5. With the increase of planting years, clay - enriched soil layer has a tendency of downward transport, especially the remarkable downward transport for the clay in topsoil, in addition, the clay ratio in subsoil has a small increase. The change features of clay particle in composite soil will result in desertification tendency for the composite topsoil and the loam tendency for the subsoil. Suitable arable layer in the entire soil profile may tend to become thicker, which is more conducive to plant growth.

\section{Introduction}

Mu Us Sandy Land is one of the four major sands in China. Its surface vegetation is sparse and short, with single community structure, and a large amount of sandstone is distributed in its territory. Pisha sandstone can be hard as a stone without water, while it will be as soft as mud in water, and 
will be run off seriously with water, is known as "environmental cancer", people suffer greatly from its soil erosion ${ }^{[1]}$, and think of it as toxic as arsenic, so it is called "arsenic sandstone". It has the characteristics of loose sand structure, leakage of water and fertilizer, low content of organic matter and nutrient, great loss of water depth and low effective availability. The combined name of land desertification and erosion of Pisha sandstone is "two evils", which seriously restricts the regional sustainable development. After research, Han Jichang et al. ${ }^{[2]}$ propose that there is a certain complementarity of the physical constitution between arsenic-sandstone and sand of Mu Us Sandy Land, after mixing it in an appropriate proportion, it can achieve the goals of improving the physical and chemical properties of aeolian sandy soil and enhancing its productivity ${ }^{[3]}$.

Soil texture is the percentage mix of soil quality per grain level in the soil, different soil grain composition determines different soil texture, and the texture type determines soil water storage, water conductivity, fertilizer conservation, nutrient supplying capability, heat preservation and temperature conductivity, which is an important evidence for evaluating soil fertility and crop suitability. With respect to the structure of Pisha sandstone, a literature study indicates that according to the classification scheme of soil granularity commonly used in China ${ }^{[4]}$, the clay content of less than $0.005 \mathrm{~mm}$ in arsenic sandstone is only $5 \% \sim 6 \%$. Clay deficiency will lead to cementing substance deficiency in the soil, the stability of which will be decreased, and the anti-erodibility will be weakened. In addition, some literature show that after compositing arsenic sandstone and sand, its capillary porosity increase from $26.33 \%$ to $44.94 \%$ with the gradual addition of arsenic-sandstone, the vent degree decreases with it, which may result in instability of compositing soil texture.

Taking advantage of chemical analysis and field plot experiment, this study analyzes the change characteristics of clay particles in the process of composite soilforming, evaluate the effect of arsenic-sandstone and sandy soilforming by the change of clay in soil texture in field plot, to provide scientific evidence for the large-scale popularization and application of composite soil technology in the agricultural planting of Mu Us Sandy Land, and provide references for future deeper study on arsenic-sand composite soil .

\section{Materials and Methods}

\subsection{General situation of test region}

In this study, arsenic sandstone and aeolian sandy soil are taken from Xiaojihan township of Yuyang district, Yulin City, Northern Shaanxi, the test region is located in Fuping County, Shaanxi Province, whose geographic location is E108 ${ }^{\circ} 57^{\prime}-109^{\circ} 26^{\prime}$, N34 ${ }^{\circ} 42^{\prime}-35^{\circ} 06^{\prime}$ ), altitude is 375.8 $-1420.7 \mathrm{~m}$, the climate belongs to the semi-arid climate region of the continental monsoon warm zone, annual total radiation is $5187.4 \mathrm{MJ} \mathrm{m}^{2}$, the annual average sunshine hours are about $2389.6 \mathrm{hs}$, annual average temperature is $13.1^{\circ} \mathrm{C}$, annual average rainfall is $527.2 \mathrm{~mm}$ (1960-1995), with big precipitation interannual variability, and the annual precipitation coefficient variation $\mathrm{CV}$ reaches $21.2 \%$. The mechanical composition of the experimental soil is shown in table 1 . 
Table 1 Physical and chemical properties of tested arsenic sandstone and sand

\begin{tabular}{|c|c|c|c|}
\hline \multicolumn{2}{|c|}{ Soil types } & Soft rock & Sand \\
\hline \multirow{3}{*}{$\begin{array}{l}\text { Proportion } \\
\text { (\%) }\end{array}$} & $\begin{array}{c}\text { Sand } \\
(0.05-2 \mathrm{~mm})\end{array}$ & 19.57 & 91.39 \\
\hline & $\begin{array}{c}\text { Silt } \\
(0.002-0.05 \\
\mathrm{mm})\end{array}$ & 72.94 & 5.51 \\
\hline & $\begin{array}{c}\text { Clay } \\
(<0.002 \mathrm{~mm})\end{array}$ & 7.49 & 3.10 \\
\hline & ure & Sandy loam & Sand \\
\hline
\end{tabular}

\subsection{Test Method}

In the test, the mixing ration of arsenic sandstone and sand is set as three types: 1:1, 1:2 and 1:5, each mixing ration is repeated for 3 times, and 9 plots are laid, each plot area is $4(2 \times 2) \mathrm{m}^{2}$. The test plots are arranged as "one" font type layout from south to north. As the plowing depth of the commonly used soil is $20-40 \mathrm{~cm}$, composite soil of different mixing proportions of arsenic sandstone and sand is covered on the $0-30 \mathrm{~cm}$ soil layer in this test plot, in order to simulate the field conditions, the profile $30-70 \mathrm{~cm}$ is filled with sandy soil.

\subsection{Sampling and analysis}

Soil texture type determines soil water storage, water conductivity, fertilizer conservation, respectively for the supply before the planting of crops (2010), after the corn harvest in 2011 and after the corn harvest in 2012, $0-5 \mathrm{~cm}, 5-10 \mathrm{~cm}, 10-15 \mathrm{~cm}, 15-20 \mathrm{~cm}, 20-25 \mathrm{~cm}, 25-30 \mathrm{~cm}, 30-40 \mathrm{~cm}$, 40-50cm, 50-70 cm deep soil sample is gathered and taken with earth drilling respectively in the test plots with different mixing proportion of arsenic sandstone and sand. Each sampling is conducted within a week after fertilization and irrigation; soil samples are collected, measured and analyzed in three times. The soil test project is soil mechanical composition, which is measured by the Mastersizer 2000 laser particle size analyzer.

\section{Results and analysis}

Soil texture (mechanical composition) is the percentage combination of soil quality accounted in per particle-size in the soil, which is one of the most fundamental physical properties of soil. Soil texture plays a very significant role in plant production and soil nutrient circulation: First, soil texture can directly affect the gap condition of soil, and the later will have an effect on ventilation, permeability and water retention and nutrient preserving capability of the soil ${ }^{[5]}$, which may further affect the absorption of water and nutrients by plants, leading to changes in productivity; Second, soil texture is closely related to moisture, air and temperature regime in soil ${ }^{[6,7]}$, which is the important basis for evaluating soil fertility and crop suitability ${ }^{[8]}$. The texture of the arsenic sandstone mixed with sand in the proportion of 1:5, 1:2 and 1:1:1 transmits from the original sandy soil to sandy loam and even loam, whose water and nutrient retention ability can be significantly 
improved. In this experiment, the effects of arsenic-sandstone and sandy soil are appraised by the transformation of soil texture in the field plot experimental field. As the experimental plot is carried out on sandy soil, the effect and trend of arsenic-sandstone and sand soil are studied through the variation of clay proportion in the soil profile.

The change of clay in the soil profile of the experimental plot 1-9 is shown in figure 1 . The figure shows the change of clay after crop harvested in 2010-2012. It can be seen from the figure that the clay content of each plot is higher in the $0-30 \mathrm{~cm}$ plough layer, and the clay content is lower below the plough layer. Along with the increase of planting years, the clay content of surface soil also tends to move downward, but the migration trend is relatively weak. The clay content in the subsoil increases slightly, which may be because the clay content itself is less, and the effect of field management measures makes the clay to move down through the void between the silt grains and sand grains. In the case of the mixing ratio of three different arsenic-sandstone and sand, the clay content in the composite soil plough layer with 1:1 ratio is the highest, while the content of clay in the 1:2 and 1:5 ratio soil plough layer is less different, which is because the clay content is higher in arsenic sandstone, and the more arsenic, the greater the proportion of clay content, while compared with silt grain, the increase of clay content is smaller. Through the adsorption of adhesive particle colloid and the formation of organic complexes with soil organic matters, soil organic carbon and nitrogen are physically protected ${ }^{[9]}$. Studies have indicated that the degree of correlation between soil clay and the content of soil organic carbon and total nitrogen may be restricted by other factors, such as climatic conditions ${ }^{[10,11]}$, chemical stability of soil organic matter and soil drainage ability. 

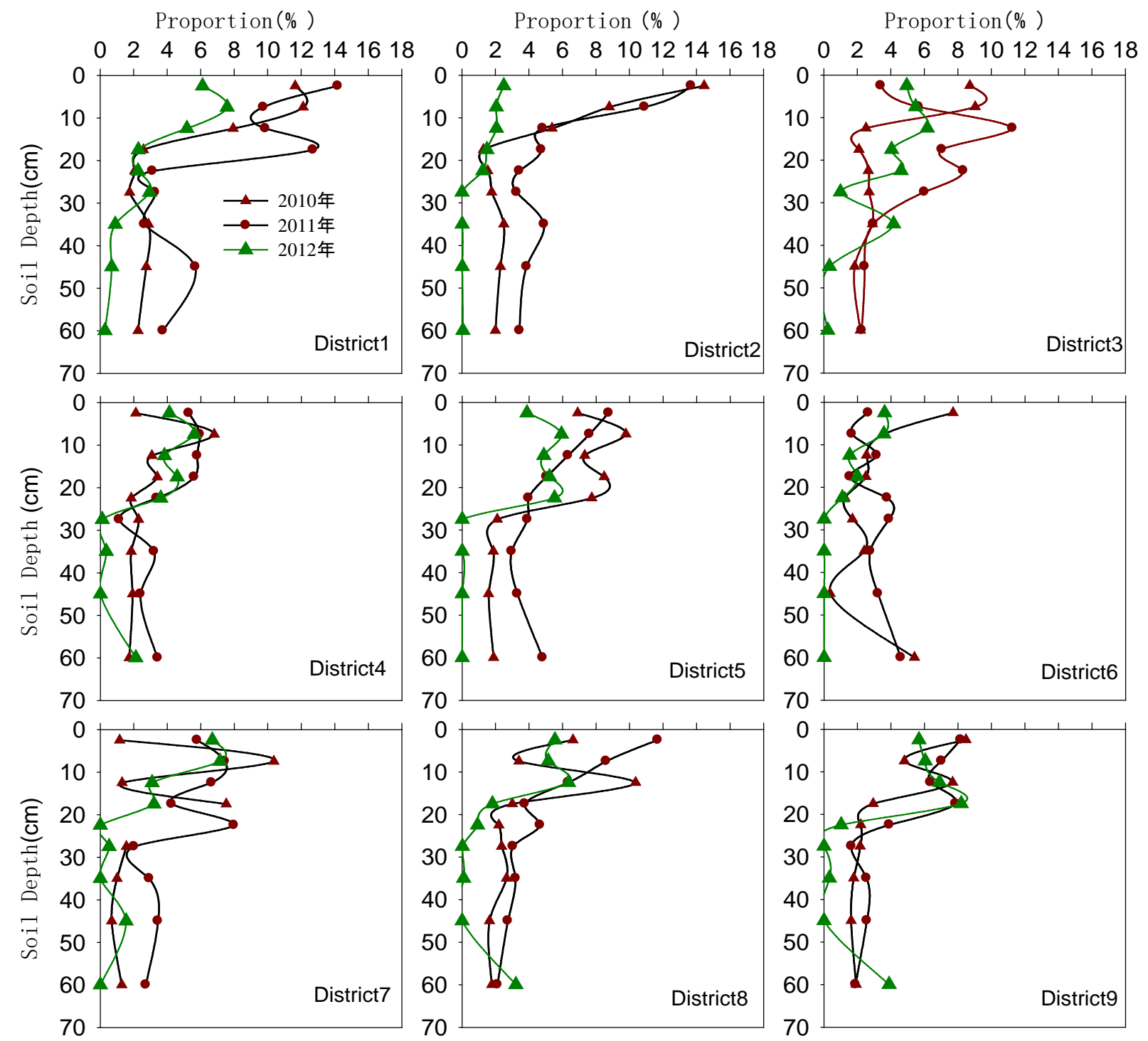

Fig1 The clay distribution in the soil profile of experimental district from 1 to 9

\section{Conclusion}

Soil texture determines soil water storage, water conductivity, nutrient preserving capability, thermal insulation, temperature conductivity, soil respiration and ventilation as well as soil tilth and so on. In this experiment, lab analysis and field plot test are used to study and analyze the migration of clay particles in the process of composite soil between arsenic sandstone and sand. The research shows that:

(1) In the composite soil of three types of arsenic sandstone and sand in different ratios, the clay mainly concentrates at $0-30 \mathrm{~cm}$ on the topsoil, the clay content in the subsoil is lower; from the mixing ratio of different arsenic sandstone and sand, the proportion of arsenic sandstone in the 1:1 composite soil is higher, so the clay content in the topsoil is the highest, with the size relationship of $1: 1,>, 1: 2,>, 1: 5$.

(2) Withe the increase of planting ages, clay enrichment soil layer tends to move downward, 
especially the downward migration trend of clay particles in the topsoil is very significant, and meanwhile, the clay proportion in the subsoil also increases slightly. In the long run, this tendency of clay downward migration will result in the desertification tendency for the topsoil of the composite soil, and the subsoil tends to loam, which will gradually form the Mongolian golden soil of "loose above and solid below", which more benefits the growth of plants and provides scientific evidence for the large-scale application of composite soil technology in the agricultural planting in Mu Us Sandy Land.

\section{Acknowledgement}

Fund Projects: Shaanxi Provincial Land Engineering Construction Group Internal research projects“Activation of soil inert nutrients by water-chemical energy” (DJNY2018-24).

\section{References}

[1] Wang Y-C, Wu Y-H, Kou Q, et al. Definition of arsenic rock zone borderline and its classification. Science of Soil and Water Conservation, 2007, 5 (1): 14-18(in Chinese)

[2]Han Jichang, Xie Jiancang, Zhang Yang. Potential Role of Feldspathic Sandstone as a Natural Water Retaining Age nt in Mu Us Sandy Land, Northwest China [J]. Chinese Geographical Science. 2012, 22 (5): 550-555.

[3]Li X-L Su Y, Qi X-H. The experimental analysis study of soft sandstone soil properties in the plateau hilly region [J]. Journal of Inner Mongolia Agricultural University, 2011, 32 (1): 315-318(in Chinese)

[4] Huang C-Y. Soil Science. Beijing: China Agriculture Press, 2005. 74-79(in Chinese)

[5] Xiong S-G. Basic Soil Science. China Agricultural University Press, Beijing, 2001

[6]Singer MJ, Munns DN. Soils, An Introduction. MacMillan Publishing Company, New York, USA, 1987.

[7]Bouma TJ, Bryla DR. On the assessment of root and soil respiration for soils of different textures: interactions with soil moisture contents and soil CO2 concentrations. Plant and Soil. 2000, 227: 215-221.

[8]Liu J-L, Ma X-Y, Zhang Z-H. Spatial Variation and Its Influence Factors of Soil Moisture Characteristic Curve in Different Soil Layers [J]. Transactions of the Chinese Society for Agricultural Machinery, 2010, 41 (1): $46-52$.

[9]Sollins P, Homann P, Caldwell B. Stabilization and destabilization of soil organic matter: mechanisms and controls. Geoderma. 1996, 74: 65-105.

[10]Sims ZR, Nielsen GA. Organic carbon in Montana soils as related to clay content and climate. Soil Science of America Journal. 1986, 50: 1269-1272.

[11]Alvarez R, Lavado RS. Climate, organic matter and clay content relationships in the Pampa and Chaco soils, Argentina. Geoderma. 1998, 83: 127-141. 